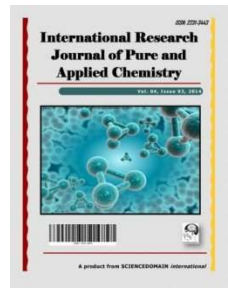

International Research Journal of Pure \& Applied Chemistry

11(2): 1-9, 2016, Article no.IRJPAC.25136 ISSN: 2231-3443, NLM ID: 101647669

SCIENCEDOMAIN international

www.sciencedomain.org

\title{
Hydrodechlorination of Aroclor 1260 in Aqueous Two-phase Mixture Catalyzed by Biogenerated Bimetallic Catalysts
}

\author{
Franco Baldi ${ }^{1}$, Michele Gallo ${ }^{1}$, Stefano Paganelli ${ }^{1}$, Riccardo Tassini ${ }^{1}$, \\ Laura Sperni ${ }^{1}$, Oreste Piccolo ${ }^{2^{*}}$, Stefano Zambon ${ }^{3,4}$, Rossano Piazza ${ }^{3}$, \\ Marta Maria Natile ${ }^{5}$ and Lidia Armelao ${ }^{5}$ \\ ${ }^{1}$ Dipartimento di Scienze Molecolari e Nanosistemi, Università Ca' Foscari Venezia, via Torino 155, \\ 30170 Venezia, Mestre, Italy. \\ ${ }^{2}$ SCSOP, Via Bornò 5, 23896 Sirtori (LC), Italy. \\ ${ }^{3}$ Dipartimento di Scienze Ambientali, Informatica e Statistica, Università Ca' Foscari Venezia, \\ via Torino 155, 30170 Venezia, Mestre, Italy. \\ ${ }^{4}$ Lab-Control Srl, via Cà Donà 545, 45030 San Martino di Venezze (RO), Italy. \\ ${ }^{5}$ Dipartimento di Scienze Chimiche, IENI - CNR and INSTM, Università di Padova, Via F. Marzolo 1, \\ 35131 Padova, Italy. \\ Authors' contributions \\ This work was carried out in collaboration among all authors. All authors read and approved the final \\ manuscript. \\ Article Information \\ DOI: 10.9734/IRJPAC/2016/25136 \\ Editor(s): \\ (1) Sung Cheal Moon, Korea Institute of Materials Science (KIMS), Industrial Technology Support Division, Changwon, \\ Republic of Korea. \\ Reviewers: \\ (1) Mitran Gheorghita, Assistant University of Bucharest, Romania. \\ (2) S. Srinivas Rao, Vidya Jyothi Institute of Technology (Autonomous), India. \\ (3) A. Veerareddy, R\&D Laboratory, Hyderabad, India. \\ Complete Peer review History: http://sciencedomain.org/review-history/13734
}

Original Research Article

Received $19^{\text {th }}$ February 2016

Accepted $9^{\text {th }}$ March 2016

Published $16^{\text {th }}$ March 2016

\section{ABSTRACT}

The PCBs are known recalcitrant and toxic pollutants and significant values of contamination could be found in water. PCBs can be hydrodechlorinated using Pd-based catalysts and hydrogen, but the research to identify more efficient heterogeneous catalysts, able to work in an aqueous phase, less sensible to deactivation and easily removable at the end of the treatment, remains a 
considerable interesting goal. A strain of Klebsiella oxytoca, DSM 29614, known to produce a specific exopolysaccaride (EPS), was grown in different media with sodium citrate or with sodium citrate plus ferric citrate, as sole energy and carbon sources under anaerobic conditions. The cultures were amended with $50 \mathrm{mg}$ of palladium as $\mathrm{Pd}\left(\mathrm{NO}_{3}\right)_{2}$ to generate $\mathrm{Pd}$-EPS $(\mathrm{Pd}$ content $13 \%$ ) or FePd-EPS (Pd content $8.4 \%$; Fe 7.4\%) species which were secreted from the cells, isolated by treatment with a cold ethanol solution (70\%) and dried under vacuum as powders. The catalytic ability of these mono- and bi-metallic species was tested in the hydrodechlorination reaction of the Aroclor 1260 PCBs mixture under aqueous biphasic conditions. Here we demonstrate that the degree of PCBs hydrodechlorination is dependent by the nature of catalyst and of base used to neutralize $\mathrm{HCl}$ produced, the bimetallic species being more active and an organic base resulting more effective. Working with a substrate/catalyst $8 / 1$ molar ratio, at $3 \mathrm{MPa}$ $\mathrm{H}_{2}$ and $60^{\circ} \mathrm{C}$ in $20 \mathrm{~h}$ a significant removal of highly chl orinated PCBs was obtained under the best conditions. The result seems promising for remediation of groundwater contaminated with PCBs.

Keywords: PCBs; Klebsiella oxytoca; biogenerated catalyst; bi-metallic polysaccharide; FePd-EPS; aqueous hydrodechlorination.

\section{INTRODUCTION}

Polychlorinated biphenyls (PCBs) are a class of 209 organic pollutants produced in complex mixtures with a different mean chlorination degree [1]. Due to their hydrophobic nature and high stability, PCBs are characterized by strong persistence in the environment, and significant values of contamination could be found in water [2]. In combination with their toxicity this stimulates researches for reducing their concentration in the ecosystem. PCBs can be hydrodechlorinated using $\mathrm{Pd}$-based catalysts that show a very high potential for the destruction of such contaminants in water [3,4]. This process may be highly efficient and selective in clean water even under mild conditions. However, palladium is very sensitive to deactivation, especially in waste-waters, due to its sequestration and precipitation with suspended organic matter. In addition, loss of $\mathrm{Pd}(0)$ reactivity is mostly due to hydrogen sulfide $\left(\mathrm{H}_{2} \mathrm{~S}\right.$ and $\mathrm{HS}^{-}$), which is ubiquitous in anoxic ecosystem [5,6]. For these reasons, Pd-based catalysts are rarely used for applications in water treatment. Until now only a few field-scale studies have investigated the use of Pd-based catalysts for hydrodechlorination (HDC) in groundwater, but the interest for its application remains very high [3,7-9]. Conventional Pd catalysts have been flanked in HDC processes also by biological dechlorination and reductive dechlorination of PCBs by anaerobic microorganisms has been demonstrated to occur [10-13]. However, biological reductive dechlorination usually is a slow reaction and it is often difficult to avoid conflicts when a mixture of indigenous and external microorganisms is applied [14].
Over the last decades, metal nanoparticles with different composition, size, shape and dispersity have been produced through the use of microorganisms. Several years ago some approaches were identified to obtain $\mathrm{Pd}(0)$ nanoparticles which were catalytically very active and more resistant to deactivation. Nanoscale metal particles (NPs) are usually characterized by high surface area to volume ratios, high levels of stepped surfaces and high surface energies showing so improved reactivity, even at high loads of compounds to be degraded, including PCBs, by dechlorination [15-22].

In this study, encouraged by our previous results obtained in the hydrodechlorination of mono and trichloro benzenes using purified biogenerated Pd-binding polysaccharide [23,24] we decided to verify the possibility to work with more complex polychlorinated biphenyls, such as Aroclor 1260.

\section{EXPERIMENTAL DETAILS}

\subsection{Materials and Instrumentation}

$\mathrm{NaHCO}_{3}, \mathrm{NH}_{4} \mathrm{Cl}, \mathrm{MgSO}_{4}, \mathrm{NaH}_{2} \mathrm{PO}_{4}, \mathrm{KCl}, \mathrm{Na}-$ citrate, $\mathrm{Fe}(\mathrm{III})$-citrate, $\mathrm{Pd}\left(\mathrm{NO}_{3}\right)_{2}, \quad \mathrm{Na}_{2} \mathrm{CO}_{3}$, ammonium acetate, Aroclor 1260, 95\% Ethanol, Methanol, were Sigma-Aldrich products. nHexane (pesticide grade) was a Romil product. Nutrient broth was a Difco product. Non-labelled PCBs were AccuStandard products. All reagents were used as received. PCB determinations were performed in full scan mode on a fused silica capillary column (HP5-MS $30 \mathrm{~m}, 0.25 \mathrm{~mm}$ x $0.25 \mu \mathrm{m}$; Agilent Technologies) installed in a ThermoFinnigan (Trace GC 2000) coupled to a quadrupole mass spectrometer (ThermoFinnigan Trace MS). The GC-MS parameters were as 
follows: solvent delay $4.5 \mathrm{~min}$; initial temperature $150^{\circ} \mathrm{C}$ for $5 \mathrm{~min}$; heating $\mathrm{ramp} 10^{\circ} \mathrm{C} / \mathrm{min}$; final temperature $300^{\circ} \mathrm{C}$ for $30 \mathrm{~min}$; injector temperature (split) $280^{\circ} \mathrm{C}$; temperature (interface) $300^{\circ} \mathrm{C}$; temperature (source) ${ }^{200}{ }^{\circ} \mathrm{C}$; detector voltage $350 \mathrm{~V}$; gas carrier flow $(\mathrm{He}) 0.8$ $\mathrm{mL} / \mathrm{min}$; injection volume $1 \mu \mathrm{L}$; mass range (amu) 35-500.

We searched for 126 different congeners, corresponding, in our conditions, to 83 chromatographic peaks, including some typical Aroclor PCBs and dioxin-like PCBs.

\subsection{Preparation of Catalysts}

The Pd-EPS (Pd content 13\%) and FePd-EPS ( $\mathrm{Pd}$ content $8.4 \%$; $\mathrm{Fe} 7.4 \%)$ catalysts were biogenerated by Klebsiella oxytoca, DSM 29614 (ex BAS-10), according to the procedure recently published [24], by adding to the culture broth, maintained under anaerobic conditions, only 50 $\mathrm{mg}$ of $\mathrm{Pd}\left(\mathrm{NO}_{3}\right)_{2}$ or $50 \mathrm{mg}$ of $\mathrm{Pd}\left(\mathrm{NO}_{3}\right)_{2}$ plus 50 $\mathrm{mg}$ of $\mathrm{Fe}(\mathrm{III})$-citrate, respectively. All cultures were first centrifuged to eliminate bacterial cells. The supernatants were treated with $800 \mathrm{ml}$ of cooled ethanol $(95 \%)$ to precipitate the metal polysaccharides. The purifications were repeated twice. Each colloidal material was finally dried out under vacuum and grinded to powder to obtain both catalysts.

\subsection{Element Determination in Poly- saccharides}

Samples $(1 \mathrm{mg})$ of dry pulverized Pd-EPS and FePd-EPS were digested with $2 \mathrm{ml}$ of aqua regia, heating the mixture at $333 \mathrm{~K}$ until a solution was obtained. The total amounts of elements were determined versus their relative standards solutions by inductively coupled plasma atomic emission spectrometry (ICP-AES) (Optima 3100, Perkin Elmer).

\subsection{Hydrodechlorination of Aroclor 1260. General Procedure}

If not otherwise indicated (see footnotes of Table 1), $2 \mathrm{mg}$ of Pd-EPS or $3 \mathrm{mg}$ of FePd-EPS were stirred in a Schlenk tube under nitrogen in $2 \mathrm{ml}$ of distilled water for about $10 \mathrm{~min}$. A solution of 7 $\mathrm{mg}$ of Aroclor $1260(\sim 0.0195 \mathrm{mmol}$ assuming MW 358 as medium value) in $1 \mathrm{ml}$ of methanol was then added to the aqueous phase to obtain a substrate/ $\mathrm{Pd}=8 / 1 \mathrm{~mol}$ ratio and as well as 1.7 $\mathrm{mg}(0.021 \mathrm{mmol})$ of ammonium acetate. The Schlenk tube was then transferred into a $150 \mathrm{ml}$ stainless steel autoclave under nitrogen, pressurized with $3 \mathrm{MPa}$ of $\mathrm{H}_{2}$ and stirred at $333^{\circ} \mathrm{K}$ for $20 \mathrm{~h}$. The reactor was then cooled to room temperature and the residual gas released. Then the sample was extracted three times via ultrasonic bath using aliquots of $10 \mathrm{~mL}$ of $\mathrm{n}$ hexane (pesticide grade, Romil). The organic phases were collected and dried on $\mathrm{Na}_{2} \mathrm{SO}_{4}$, concentrated to $100 \mu \mathrm{L}$ using a nitrogen flow (Turbovap 2, Caliper Science) and analyzed by GC-MS.

\section{RESULTS AND DISCUSSION}

In Table 1 results of different runs obtained by changing some reaction parameters (catalyst, amount and type of base) are reported. A\% of the individual congener is calculated by integrating all considered peaks (83) and dividing the area of the individual congener for the total area. For each homologous class (same number of chlorine atoms) the areas of the components of the class are added together and similarly related to the total area. To rationalize the identification of defined PCB components in Table 2, the method, developed by K. Ballschmiter and M. Zell [25] and based on the IUPAC rules of substituent characterization in biphenyls, is followed. The number of position according to this arrangement is taken as an abbreviation for the PCB structure. The distribution of congeners before and after the reactions is better visualized in Fig. 1. In Fig. 2 is reported the chromatogram of used Aroclor 1260 and in Fig. 3 the chromatogram of the final mixture in run 5 . In absence of any palladium catalyst, as expected, no significant variation of congeners distribution of Aroclor 1260 occurs (run 1). On the basis of our recent good results in the hydrodechlorination of 1,2,4-trichlorobenzene [24], initially we worked in absence of a base (runs 2 and 3), so avoiding to neutralize the $\mathrm{HCl}$ formed. The distribution displacement of PCBs concentrations from the heaviest $\left(\mathrm{n}^{\circ} \mathrm{Cl} 6-10\right)$ to the lightest $\left(\mathrm{n}^{\circ} \mathrm{Cl} \quad 0-5\right)$ compounds resulted increased, suggesting an encouraging improvement of the hydrodechlorination process. Surprisingly the mono metallic catalyst worked slightly better than the bimetallic catalyst while in the hydrodechlorination of 1,2,4-trichlorobenzene an opposite result was found [24]. In the presence of an inorganic base a relevant loss of activity of the catalyst was observed (run 4); on the contrary a synergic positive effect was found using ammonium acetate as base with the most relevant decrease in the concentrations of $\mathrm{PCBs}$ with higher number of chlorine atoms $\left(\mathrm{n}^{\circ} \mathrm{Cl} 6-10\right.$; 
$-59 \%)$. In particular it is to underline the significant $A \%$ decrease , between $-49 \%$ and $85 \%$, of some dioxin-like PCBs congeners: BZ $118,156,157,167,170,180,189$ (see Table 2, where in the column Aroclor 1260 the $\mathrm{A} \%$ of the congeners present in the original PCBs mixture are reported, while in the columns Run 2, Run 3 and Run 5 are reported the $A \%$ of the single congeners found after the hydrodechlorination experiments carried out at different reaction conditions described in Table 1). Finally a preliminary attempt to recycle the catalyst embedded in the aqueous phase was, in our opinion, positive (run 6); the catalyst was still enough active, even if a loss of activity was observed. However we believe that the observed decreased activity is mostly due to unwanted and not quantifiable losses of catalyst suspended in the aqueous phase, during the work-up and recycle.

Table 1. Results in the hydrodechlorination experiments starting from Aroclor 1260

\begin{tabular}{|c|c|c|c|c|c|c|c|}
\hline \multirow[t]{2}{*}{$\mathrm{n}^{\circ} \mathrm{Cl}$} & Aroclor $1260^{\mathrm{a}}$ & Run1 $^{\text {b }}$ & Run $2^{c}$ & Run $3^{d}$ & Run $4^{\mathrm{e}}$ & Run $5^{f}$ & Run $6^{g}$ \\
\hline & $A \%^{h}$ & $A \%^{h}$ & $A \%{ }^{h}$ & $A \%^{h}$ & $A \%^{h}$ & $A \%^{h}$ & $A \%^{h}$ \\
\hline 0 & 0.02 & 0.03 & 0.21 & 2.57 & 0.05 & 3.37 & 0.17 \\
\hline 1 & 0.06 & 0.06 & 0.27 & 1.21 & 0.40 & 2.04 & 0.38 \\
\hline 2 & 0.25 & 0.17 & 1.28 & 4.28 & 0.67 & 8.41 & 2.48 \\
\hline 3 & 0.52 & 0.43 & 4.97 & 8.59 & 1.82 & 15.40 & 5.30 \\
\hline 4 & 0.61 & 0.45 & 8.88 & 10.62 & 2.88 & 14.42 & 5.21 \\
\hline 5 & 10.6 & 10.3 & 25.5 & 21.4 & 14.5 & 20.18 & 14.8 \\
\hline 6 & 46.1 & 46.9 & 37.6 & 29.7 & 43.0 & 21.22 & 38.9 \\
\hline 7 & 34.0 & 33.3 & 18.0 & 17.8 & 29.9 & 12.24 & 26.9 \\
\hline 8 & 7.00 & 7.46 & 3.07 & 3.50 & 6.26 & 2.48 & 5.22 \\
\hline 9 & 0.80 & 0.84 & 0.28 & 0.31 & 0.49 & 0.23 & 0.59 \\
\hline 10 & 0.04 & 0.01 & 0.01 & 0.00 & 0.01 & 0.00 & 0.03 \\
\hline
\end{tabular}

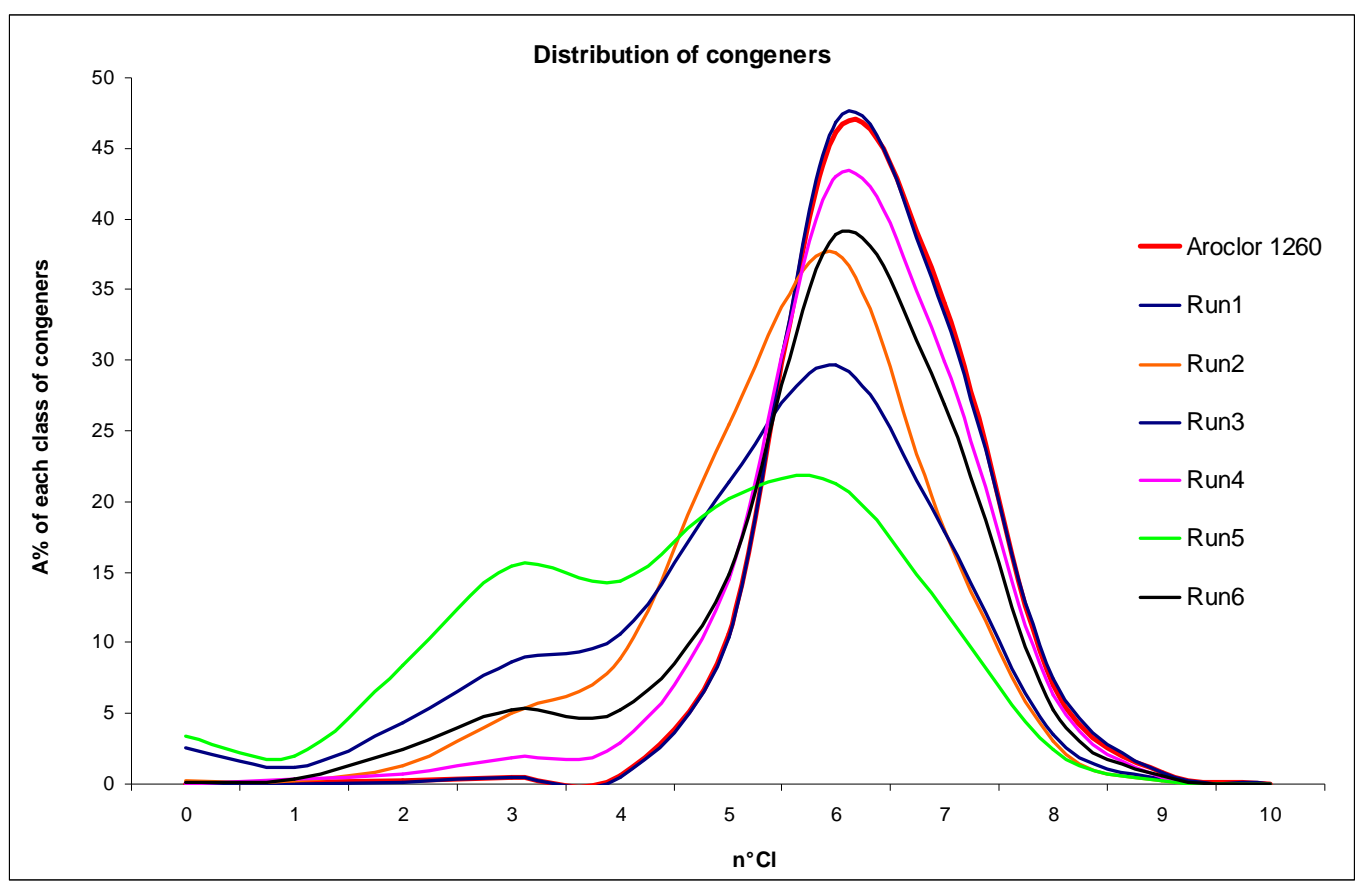

Fig. 1. Distribution and area \% of congeners in Aroclor 1260 and in the different experiments 


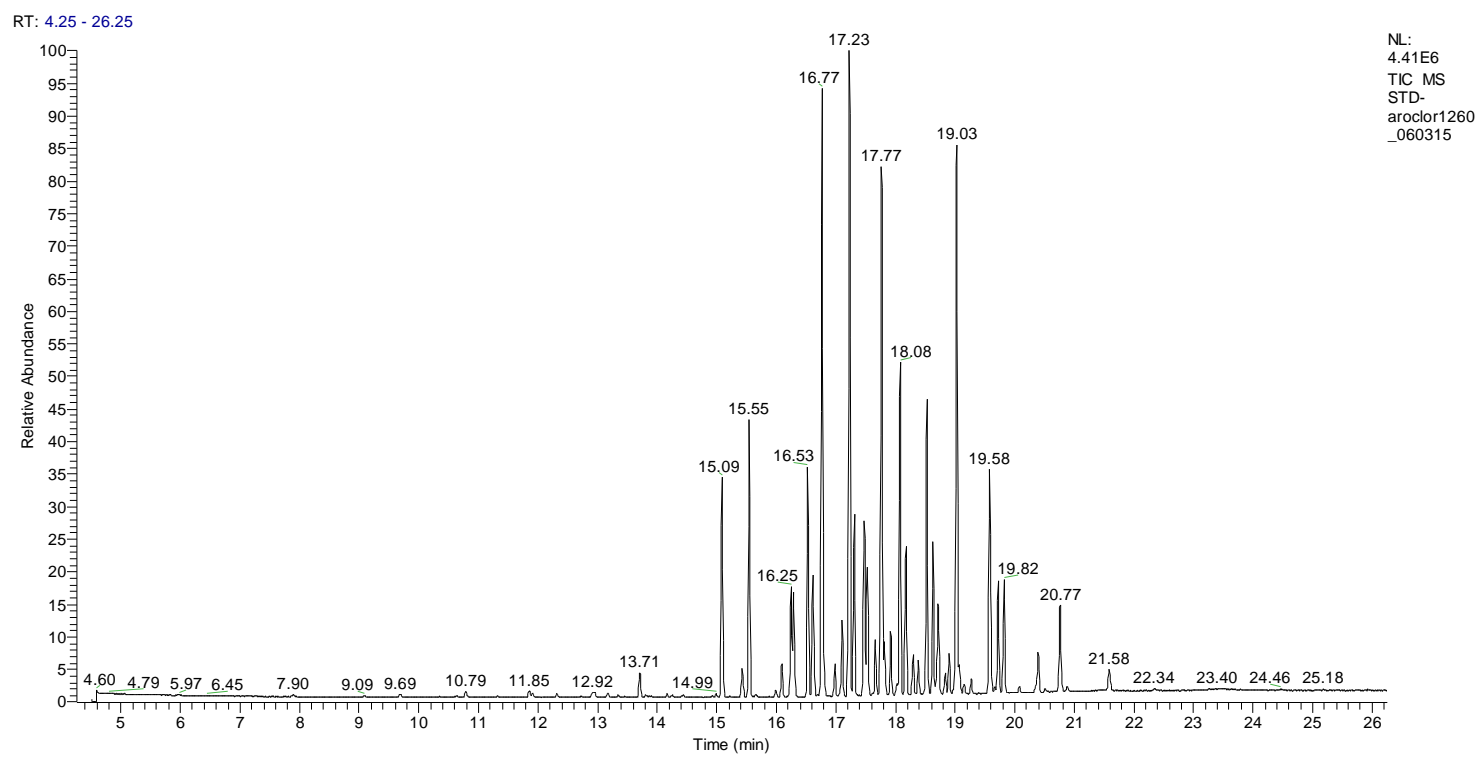

Fig. 2. Chromatogram of used Aroclor 1260

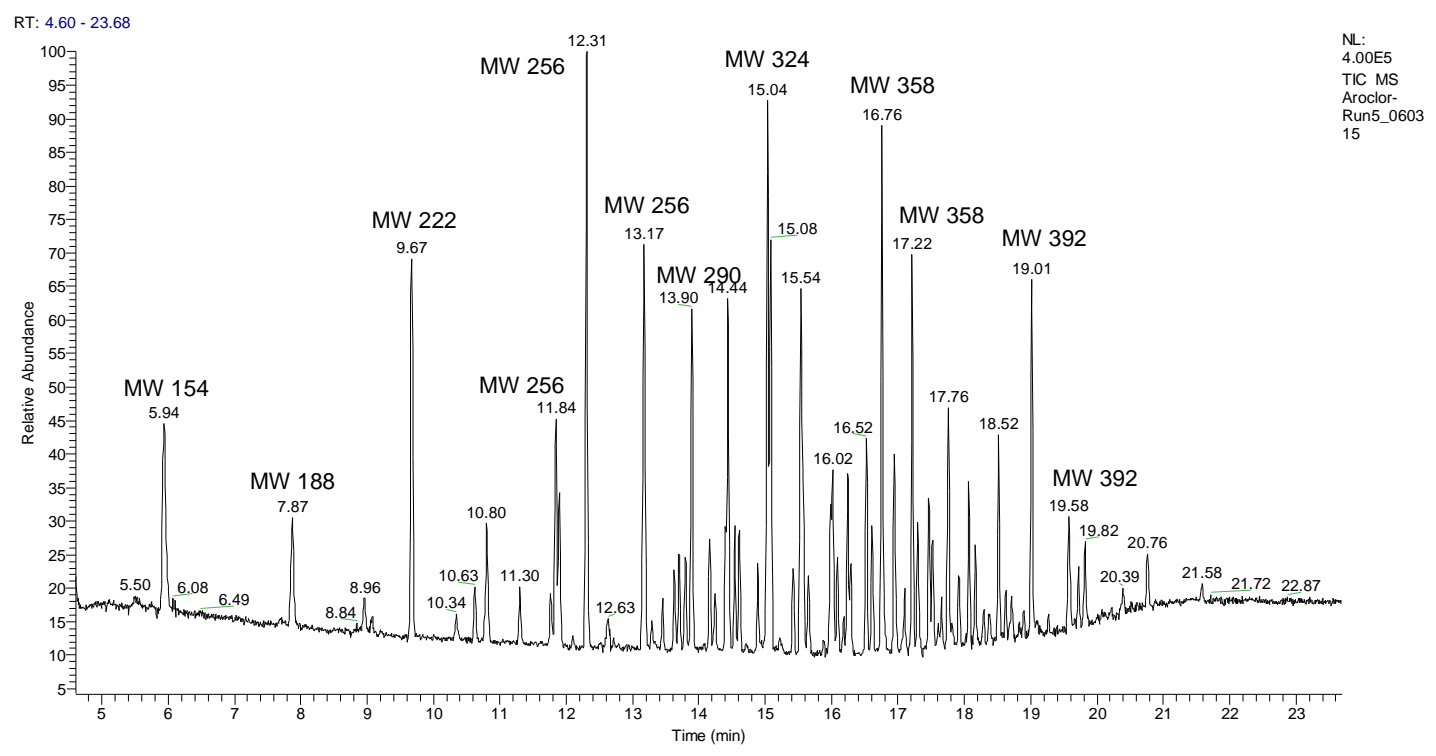

Fig. 3. Chromatogram of product mixture (run 5)

Table 2. PCB concentrations (A\%) of analyzed Aroclor 1260 and of three hydrogenated mixtures

\begin{tabular}{lllllllll}
\hline$\#$ & $\mathbf{n}^{\circ} \mathbf{C l}$ & $\mathbf{M W}$ & $\mathbf{B Z}^{\mathbf{1}}$ & ID $^{\mathbf{2}}$ & $\begin{array}{l}\text { Aroclor 1260 } \\
\mathbf{A} \%\end{array}$ & $\begin{array}{c}\text { Run 2 } \\
\mathbf{A} \%\end{array}$ & $\begin{array}{c}\text { Run 3 } \\
\mathbf{A} \%\end{array}$ & $\begin{array}{l}\text { Run 5 } \\
\mathbf{A} \%\end{array}$ \\
\hline 1 & Biphenyl & 154 & & STD & 0.01 & 0.21 & 2.57 & 3.37 \\
2 & 1 & 188 & & no ID & 0.04 & 0.21 & 1.02 & 1.49 \\
3 & 1 & 188 & & no ID & & 0.04 & 0.16 & 0.38 \\
4 & 1 & 188 & & no ID & 0.01 & 0.03 & 0.02 & 0.17 \\
$\mathbf{5}$ & $\mathbf{2}$ & $\mathbf{2 2 2}$ & $\mathbf{4}$ & STD & $\mathbf{0 . 0 6}$ & $\mathbf{0 . 5 1}$ & $\mathbf{2 . 8 1}$ & $\mathbf{4 . 6 6}$ \\
6 & 2 & 222 & & no ID & 0.01 & 0.03 & 0.11 & 0.32 \\
\hline
\end{tabular}




\begin{tabular}{|c|c|c|c|c|c|c|c|c|}
\hline$\#$ & $\mathrm{n}^{\circ} \mathrm{Cl}$ & MW & $\mathrm{BZ}^{1}$ & $I^{2}$ & $\begin{array}{l}\text { Aroclor } 1260 \\
\text { A\% }\end{array}$ & $\begin{array}{l}\text { Run } 2 \\
\text { A\% }\end{array}$ & $\begin{array}{l}\text { Run } 3 \\
\text { A\% }\end{array}$ & $\begin{array}{l}\text { Run } 5 \\
\text { A\% }\end{array}$ \\
\hline 7 & 2 & 222 & & no ID & 0.02 & 0.15 & 0.45 & 0.64 \\
\hline 8 & 2 & 222 & 5 & STD & 0.11 & 0.30 & 0.49 & 1.54 \\
\hline 9 & 3 & 256 & & no ID & 0.01 & 0.19 & 0.49 & 0.65 \\
\hline 10 & 2 & 222 & & no ID & & 0.07 & 0.20 & 0.54 \\
\hline 11 & 3 & 256 & 18 & STD & 0.11 & 0.82 & 1.45 & 2.02 \\
\hline 12 & $2+3^{3}$ & & & no ID & 0.06 & 0.43 & 0.46 & 1.43 \\
\hline 13 & 3 & 256 & & no ID & & 0.08 & 0.12 & 0.11 \\
\hline 14 & 3 & 256 & & no ID & 0.07 & 0.92 & 2.79 & 6.12 \\
\hline 15 & 3 & 256 & & no ID & 0.01 & 0.05 & 0.05 & 0.09 \\
\hline 16 & 3 & 256 & & no ID & & 0.03 & 0.01 & 0.04 \\
\hline 17 & 3 & 256 & 31 & STD & 0.09 & 0.07 & 0.03 & 0.04 \\
\hline 18 & 3 & 256 & 28 & STD & 0.07 & 0.06 & 0.01 & 0.02 \\
\hline 19 & 3 & 256 & & no ID & 0.08 & 2.17 & 3.17 & 5.10 \\
\hline 20 & 3 & 256 & & no ID & 0.03 & 0.06 & 0.05 & 0.27 \\
\hline 21 & 4 & 290 & & no ID & & 0.28 & 0.43 & 0.45 \\
\hline 22 & 4 & 290 & & no ID & & 0.35 & 0.74 & 0.82 \\
\hline 23 & 4 & 290 & 52 & STD & 0.39 & 1.00 & 0.85 & 1.03 \\
\hline 24 & 4 & 290 & 49 & $\mathrm{cfr}$ & 0.05 & 0.79 & 0.56 & 0.93 \\
\hline 25 & $4^{3}$ & 290 & $47+48$ & cfr & & 1.77 & 2.37 & 3.44 \\
\hline 26 & 4 & 290 & 44 & STD & 0.06 & 0.83 & 1.11 & 1.06 \\
\hline 27 & $3+4^{3}$ & & & no ID & 0.03 & 0.61 & 0.38 & 0.50 \\
\hline 28 & 4 & 290 & & no ID & 0.03 & 2.39 & 3.05 & 4.42 \\
\hline 29 & 5 & 324 & 96 & $\mathrm{cfr}$ & & 0.43 & 0.65 & 1.11 \\
\hline 30 & 4 & 290 & 74 & $\mathrm{cfr}$ & & 0.40 & 0.83 & 1.22 \\
\hline 31 & 4 & 290 & 70 & cfr & 0.02 & 0.61 & 0.45 & 0.78 \\
\hline 32 & 4 & 290 & 66 & $\mathrm{cfr}$ & 0.06 & 0.17 & 0.04 & 0.03 \\
\hline 33 & 5 & 324 & & no ID & & 3.44 & 3.15 & 4.47 \\
\hline 34 & 5 & 324 & & no ID & 3.51 & 5.04 & 3.99 & 3.63 \\
\hline 35 & 5 & 324 & & no ID & 0.48 & 1.09 & 0.91 & 0.80 \\
\hline 36 & 5 & 324 & 101 & STD & 4.37 & 6.03 & 4.17 & 3.67 \\
\hline 37 & 5 & 324 & 99 & cfr & & 0.83 & 1.74 & 1.03 \\
\hline 38 & 5 & 324 & 119 & cfr & 0.04 & 1.32 & 0.65 & 0.65 \\
\hline 39 & 5 & 324 & 83 & $\mathrm{cfr}$ & 0.10 & 1.51 & 1.76 & 1.08 \\
\hline 40 & 5 & 324 & 97 & cfr & & 1.03 & 1.69 & 1.66 \\
\hline 41 & $5^{3}$ & 324 & $87+115$ & $\mathrm{cfr}$ & 0.52 & 1.81 & 1.04 & 0.87 \\
\hline 42 & 5 & 324 & 85 & $\mathrm{cfr}$ & & 0.87 & 0.31 & 0.32 \\
\hline 43 & 6 & 358 & 136 & $\mathrm{cfr}$ & 1.52 & 2.10 & 1.65 & 1.50 \\
\hline 44 & 5 & 324 & 110 & cfr & 1.66 & 2.11 & 1.34 & 0.89 \\
\hline 45 & 6 & 358 & 151 & cfr & 3.64 & 3.57 & 2.78 & 1.92 \\
\hline 46 & 6 & 358 & 135 & cfr & 2.12 & 2.20 & 1.85 & 1.18 \\
\hline 47 & $5+6^{3}$ & & $118+149$ & STD & 10.18 & 9.12 & 7.34 & 5.16 \\
\hline 48 & 6 & 358 & & no ID & & 1.58 & 1.60 & 2.02 \\
\hline 49 & 6 & 358 & & no ID & 0.50 & 0.29 & 0.16 & 0.06 \\
\hline 50 & 6 & 358 & & no ID & 1.25 & 1.16 & 0.83 & 0.42 \\
\hline 51 & 6 & 358 & 153 & STD & 10.30 & 6.06 & 5.10 & 3.38 \\
\hline 52 & 6 & 358 & 132 & cfr & 2.79 & 2.96 & 2.15 & 1.21 \\
\hline 53 & 6 & 358 & 141 & cfr & 2.75 & 2.06 & 2.28 & 1.36 \\
\hline 54 & 7 & 392 & 179 & $\mathrm{cfr}$ & 2.03 & 1.60 & 1.30 & 1.00 \\
\hline 55 & 6 & 358 & 137 & cfr & & 0.46 & 0.21 & 0.08 \\
\hline 56 & 7 & 392 & 176 & cfr & 0.85 & 0.78 & 0.54 & 0.44 \\
\hline 57 & 6 & 358 & 138 & STD & 9.28 & 4.81 & 3.18 & 2.47 \\
\hline
\end{tabular}




\begin{tabular}{|c|c|c|c|c|c|c|c|c|}
\hline$\#$ & $\mathrm{n}^{\circ} \mathrm{Cl}$ & MW & $\mathrm{BZ}^{1}$ & $I^{2}$ & $\begin{array}{l}\text { Aroclor } 1260 \\
\mathrm{~A} \%\end{array}$ & $\begin{array}{c}\text { Run } 2 \\
\text { A\% }\end{array}$ & $\begin{array}{c}\text { Run } 3 \\
\text { A\% }\end{array}$ & $\begin{array}{l}\text { Run } 5 \\
\text { A\% }\end{array}$ \\
\hline 58 & 6 & 358 & & no ID & 0.59 & 0.36 & 0.17 & 0.18 \\
\hline 59 & 7 & 392 & 178 & $\mathrm{cfr}$ & 0.99 & 1.08 & 1.53 & 0.72 \\
\hline 60 & 7 & 392 & 187 & $\mathrm{cfr}$ & 0.16 & 0.14 & 0.06 & 0.02 \\
\hline 61 & 7 & 392 & 183 & cfr & 5.13 & 2.45 & 2.44 & 1.48 \\
\hline 62 & 7 & 392 & 185 & cfr & 2.33 & 1.26 & 1.20 & 0.84 \\
\hline 63 & 6 & 358 & 167 & STD & 0.72 & 0.84 & 0.37 & 0.29 \\
\hline 64 & 7 & 392 & 174 & cfr & 0.54 & 0.35 & 0.51 & 0.25 \\
\hline 65 & 7 & 392 & 177 & cfr & 4.58 & 2.99 & 3.00 & 1.92 \\
\hline 66 & 7 & 392 & 171 & cfr & 2.43 & 0.82 & 0.53 & 0.46 \\
\hline 67 & $6+7^{3}$ & & $156+173$ & $\mathrm{cfr}+$ STD & 1.84 & 0.80 & 0.44 & 0.39 \\
\hline 68 & $6+8^{3}$ & & $157+197$ & $\mathrm{cfr}+$ STD & 0.31 & 0.24 & 0.24 & 0.07 \\
\hline 69 & 7 & 392 & & no ID & 0.65 & 0.35 & 0.30 & 0.25 \\
\hline 70 & 7 & 392 & 180 & STD & 8.88 & 3.99 & 4.55 & 3.27 \\
\hline 71 & 7 & 392 & 193 & cfr & 0.32 & 0.06 & 0.04 & 0.06 \\
\hline 72 & 7 & 392 & 191 & cfr & 0.14 & 0.05 & 0.01 & 0.01 \\
\hline 73 & 8 & 426 & 199 & STD & 0.23 & 0.18 & 0.07 & 0.15 \\
\hline 74 & $7^{3}$ & & $170+190$ & $\mathrm{cfr}$ & 4.25 & 1.60 & 1.60 & 1.33 \\
\hline 75 & 8 & 426 & 203 & $\mathrm{cfr}$ & 1.69 & 0.58 & 0.71 & 0.63 \\
\hline 76 & 8 & 426 & 196 & cfr & 1.93 & 0.98 & 1.17 & 0.79 \\
\hline 77 & 7 & 392 & 189 & STD & 0.13 & 0.04 & 0.02 & 0.02 \\
\hline 78 & $8+9^{3}$ & & $195+208$ & $\mathrm{cfr}$ & 0.66 & 0.23 & 0.29 & 0.10 \\
\hline 79 & 9 & 460 & 207 & cfr & 0.07 & 0.01 & 0.01 & 0.01 \\
\hline 80 & 8 & 426 & 194 & STD & 1.57 & 0.56 & 0.94 & 0.58 \\
\hline 81 & 8 & 426 & 205 & cfr & 0.08 & 0.01 & 0.01 & 0.02 \\
\hline 82 & 9 & 460 & 206 & cfr & 0.42 & 0.16 & 0.15 & 0.16 \\
\hline 83 & 10 & 494 & 209 & STD & 0.05 & 0.01 & 0.00 & 0.00 \\
\hline
\end{tabular}

${ }^{1} B Z=$ Congener number according to ref. [25]; ${ }^{2}$ STD = Identification by standard injection; cfr = Tentatively identified by retention time and elution order according to ref. [26]; no ID when a defined congener was not identified but only the number of chlorine atoms was determined; ${ }^{3}$ Determined by mass analysis

\section{CONCLUSION}

In conclusion, the development of new biogenerated metal catalysts, prepared by a greener synthetic approach, is a highly promising area. Noteworthy, these new types of Pd catalysts were purified by alcoholic extraction of exopolysaccharide binding metals in order to eliminate cells as much as possible from culture broth: this procedure distinguishes our catalysts from other biogenerated ones containing whole cells [27]. In our opinion, they present less drawbacks and risks, therefore they are more reliable for use and reuse in comparative experiments with respect to other conventional heterogeneous Pd catalysts. The use of these catalysts, embedded in the aqueous phase and active only in the presence of water, may improve the reductive dehalogenation of pollutants present in aqueous environment, in particular those containing a higher number of chlorine atoms that are more recalcitrant for a microbial dehalogenation. At the present, FePdEPS, combined with ammonium acetate, results the more efficient catalyst in this reaction that might be improved using a continuous flow reactor as reported in the literature for other dehalogenation reactions [6]; furthermore it is prepared easier than the monometallic catalyst and contains a lower amount of expensive precious metal.

\section{COMPETING INTERESTS}

Authors have declared that no competing interests exist.

\section{REFERENCES}

1. Erickson MD. Analytical chemistry of PCBs, $2^{\text {nd }}$ ed. CRC Press / Lewis, New York; 1997.

2. Moret I, Gambaro A, Piazza R, Ferrari $S$, Manodori L. Determination of polychlorobiphenyl congeners (PCBs) in the surface water of the Venice lagoon. Mar. Pollut. Bull. 2005;50:167. 
3. Navon R, Eldad S, Mackenzie K, Kopinke FD. Protection of palladium catalysts for hydrodechlorination of chlorinated organic compounds in wastewaters. Appl. Catal. B Environ. 2012;119-120:241.

4. Wu BZ, Chen HY, Wang SJ, Wai, Liao W, Chiu $\mathrm{KH}$. Reductive dechlorination for remediation of polychlorinated biphenyls. Chemosphere. 2012;88:757.

5. Monguchi $Y$, Ishihara S, Ido M, Nikawa M, Kamiya K, Nagase H, Sawama Y, Saji H. Pilot-plant study of the PCB degradation at ambient temperature and pressure. Org. Proc. Res. Dev. 2010;14:1140.

6. Hildebrand $\mathrm{H}$, Mackenzie $\mathrm{K}$, Kopinke FD. $\mathrm{Pd} / \mathrm{Fe}_{3} \mathrm{O}_{4}$ nano-catalysts for selective dehalogenation in wastewater treatment processes-Influence of water constituents Appl. Catal. B Environ. 2009; 91:389.

7. Kopinke FD, Angels-Wedler D, Fritsch D, Mackenzie K. Pd-catalyzed hydrodechlorination of chlorinated aromatics in contaminated waters-effects of surfactants, organic matter and catalyst protection by silicone coating. Appl. Catal. B Environ. 2010;96:323.

8. Diaz E, Mohedano AF, Casas JA, Calvo L, Gilarranz MA, Rodriguez JJ. Comparison of activated carbon-supported $\mathrm{Pd}$ and $\mathrm{Rh}$ catalysts for aqueous-phase hydrodechlorination. Appl. Catal. B Environ. 2011;106: 469.

9. Chaplin BP, Reinhard M, Schneider WF, Schüth C, Shapley JR, Strathmann TJ, Werth CJ. Critical review of Pd-based catalytic treatment of priority contaminants in water. Environ. Sci. Technol. 2012;46: 3655.

10. Fagervold SK, May HD, Sowers KR. Microbial reductive dechlorination of Aroclor 1260 in Baltimore Harbor sediment microcosms is catalyzed by three phylotypes within the Phylum Chloroflexi. Appl. Environ. Microbiol. 2007;73:3009.

11. Vasilyeva GK, Strjakova ER. Bioremediation of soils and sediments contaminated by polychlorinated biphenyls. Microbiology 2007;76:639.

12. Zanaroli G, Balloi A, Negroni A, Borruso L, Daffonchio D, Fava F. A Chloroflexi bacterium dechlorinates polychlorinated biphenyls in marine sediments under in situ-like biogeochemical conditions. J. Hazard. Mater. 2012;209-210:449.

13. Zanaroli G, Negroni A, Vignola M, Nuzzo A, Shu HY, Fava F. Enhancement of microbial reductive dechlorination of polychlorinated biphenyls (PCBs) in a marine sediment by nanoscale zerovalent iron (NZVI) particles. J. Chem. Technol. Biotechnol. 2012;87:1246.

14. Juergen $\mathrm{W}, \mathrm{Wu} Q$. Microbial reductive dehalogenation of polychlorinated biphenyls. FEMS Microbiol. Ecol. 2000; 32:1.

15. Facchin G, Carturan G, Campostrini R, Gialanella S, Lutterotti L, Armelao L, Marcì G, Palmisano L, Sclafani A. Sol-gel synthesis and characterisation of $\mathrm{TiO}_{2}-$ anatase powders containing nanometric platinum particles employed as catalysts for 4-Nitrophenol photodegradation. J. SolGel Sci. Technol. 2000;18:29.

16. Armelao L, Bottaro G, Campostrini R, Gialanella S, Ischia M, Poli F, Tondello E. Synthesis and structural evolution of mesoporous silica-silver nanocomposites. Nanotechnology. 2007;18:155606.

17. Armelao L, Belli Dell'Amico D, Braglia R, Calderazzo F, Garbassi F, Marra G, Merigo A. Loading silica with metals (palladium or platinum) under mild conditions by using well-defined molecular precursors. Dalton Trans. 2009;5559.

18. De Windt W, Aelterman P, Verstraete W. Bioreductive deposition of palladium (0) nanoparticles on Shewanella oneidensis with catalytic activity towards reductive dechlorination of polychlorinated biphenyls. Environ. Microbiol. 2005;7:314.

19. Narayanan KB, Sakthivel N. Biological synthesis of metal nanoparticles by microbes. Adv. Colloid. Interface Sci. 2010;156:1.

20. Lloyd JR, Yong P, Macaskie LE. Enzymatic recovery of elemental palladium by using sulfate-reducing bacteria. Appl. Environ. Microbiol. 1998;64:4607.

21. Baxter-Plant VS, Mikheenko IP, Macaskie LE. Sulphate-reducing bacteria, palladium and the reductive dehalogenation of chlorinated aromatic compounds. Biodegradation. 2003;14:83.

22. De Corte S, Hennebel T, De Gusseme B, Verstraete W, Boon N. Bio-palladium: from metal recovery to catalytic applications. Microbial. Biotech. 2012;5:5.

23. Baldi F, Marchetto D, Paganelli $S$, Piccolo O. Bio-generated metal binding polysaccharides as catalysts for synthetic applications and organic pollutant transformations. New Biotechnol. 2011; 29:74. 
24. Arčon I, Paganelli S, Piccolo O, Gallo M, Vogel-Mikuš K, Baldi F. XAS analysis of iron and palladium bonded to a polysaccharide produced anaerobically by a strain of Klebsiella oxytoca. J. Synchrotron. Rad. 2015;22:1215.

25. Ballschmiter K, Zell M. Analysis of polychlorinated biphenyls (PCB) by glass capillary gas chromatography. Fresenius Z. Anal. Chem. 1980;302:20.

26. Lulek J, Opielewicz M, Szyrwińska K, Milanowski B. Application of a retention database to the identification of individual polychlorinated biphenyl congeners in Aroclors mixture using selected polychlorinated biphenyls as a reference series. Analytica Chimica Acta 2005; 540:25

27. Schröfel A, Kratošová $G$, Šafařík I, Šafaříková M, Raška I, Shor LM. Applications of biosynthesized metallic nanoparticles - A review. Acta Biomaterialia. 2014;10:4023.

(C) 2016 Baldi et al.; This is an Open Access article distributed under the terms of the Creative Commons Attribution License (http://creativecommons.org/licenses/by/4.0), which permits unrestricted use, distribution, and reproduction in any medium, provided the original work is properly cited.

Peer-review history:

The peer review history for this paper can be accessed here: http://sciencedomain.org/review-history/13734 